\title{
Correction to: A new approach to modelling the input-output structure of regional economies using non-survey methods
}

Anthony T. Flegg ${ }^{1 *}$, Guiseppe R. Lamonica ${ }^{2}$, Francesco M. Chelli², Maria C. Recchioni ${ }^{2}$ and Timo Tohmo ${ }^{3}$

The original article can be found online at https://doi. org/10.1186/s40008-021$00242-8$

\section{*Correspondence:}

tony.flegg@uwe.ac.uk

1 Department of Accounting

Economics and Finance,

University of the West

of England, Coldharbour

Lane, Bristol BS16 1QY, UK

Full list of author information

is available at the end of the article

\section{Correction to: Economic Structures (2021) 10:12 \\ https://doi.org/10.1186/s40008-021-00242-8}

The original version of this article (Flegg et al. 2021) unfortunately contained an error in the presentation of two equations. The correct versions are given in this erratum.

$$
\hat{a}_{i j}^{r}=\left\{\begin{array}{lrr}
\left(\mathrm{SLQ}_{i}\right)^{\alpha} a_{i j}^{n}\left(x_{j}^{r} / x_{j}^{n}\right)^{\beta} & \text { if } & \mathrm{SLQ}_{i} \leq 1 \\
{\left[0.5 \tanh \left(\mathrm{SLQ}_{i}-1\right)+1\right]^{\alpha} a_{i j}^{n}\left(x_{j}^{r} / x_{j}^{n}\right)^{\beta}} & \text { if } & \mathrm{SLQ}_{i}>1
\end{array}\right.
$$

Also, on the same page, the 2DLQ method is, in two instances, erroneously referred to as the 2DLS method.

The original article has also been corrected.

\section{Author details}

'Department of Accounting, Economics and Finance, University of the West of England, Coldharbour Lane, Bristol BS16 $1 \mathrm{QY}$, UK. ${ }^{2}$ Faculty of Economics, Università Politecnica delle Marche, Ancona, Italy. ${ }^{3}$ School of Business and Economics, University of Jyväskylä, PO Box 35, 40014 Jyvaskyla, Finland.

Published online: 28 September 2021

Reference

Flegg AT, Lamonica GR, Chelli FM, Recchioni MC, Tohmo T (2021) A new approach to modelling the input-output structure of regional economies using non-survey methods. Economic Structures. 10:12. https://doi.org/10.1186/ s40008-021-00242-8

Publisher's Note

Springer Nature remains neutral with regard to jurisdictional claims in published maps and institutional affiliations. author(s) and the source, provide a link to the Creative Commons licence, and indicate if changes were made. The images or other third party material in this article are included in the article's Creative Commons licence, unless indicated otherwise in a credit line to the material. If material is not included in the article's Creative Commons licence and your intended use is not permitted by statutory regulation or exceeds the permitted use, you will need to obtain permission directly from the copyright holder. To view a copy of this licence, visit http:// creativecommons.org/licenses/by/4.0/. 